\title{
The latest developments of China's death penalty reforms
}

\begin{abstract}
This paper examines the latest development of China's death penalty reforms in the recent decade. The goal of death penalty reforms was to protect human rights of the accused. This paper will show that, if the reforms are considered from the perspective of human rights of the accused, it is clear that their intent has been frustrated by legal loopholes in the death penalty system. The legal loopholes still allow death sentences for many non-violent crimes. Although the 2011 and 2015 Amendments to Criminal Law of the PRC greatly reduces the number of crimes publishable by death in law, further substantive reforms will be suggested.
\end{abstract}

Keywords: China' death penalty reforms, wrongful convictions, the latest development, substantive human rights progress
Volume 7 Issue I - 2019

\author{
Jiang $\mathrm{Na}$, 'Wang Yue ${ }^{2}$ \\ 'Professor of law, Beijing Normal University, China \\ ${ }^{2}$ LLM Candidate from College for Criminal Law Science, Beijing \\ Normal University, PRC
}

Correspondence: Jiang $\mathrm{Na}$, Professor of law, Beijing Normal University (China), Ph.D. in Law (UK), Deputy General-

Secretary of the International Association of Penal Law (AIDP)

China Branch, China, Email na.jiang@bnu.edu.cn

Received: January 04, 2019 | Published: January 29, 2019

\section{Introduction}

The death penalty in China is generally accepted as one of major human rights issues during international dialogues. In the recent decade, China has undertaken great efforts to reduce the execution or death sentences in capital cases by many means. Following Amendment VIII to Criminal Law of the PRC in 2011 (2011 Amendment), China adopted Amendment IX to Criminal Law of the PRC in 2015 (2015 Amendment $)^{1}$ in order to further decrease crimes punishable by death in law and to shrink the applicable scope of the death penalty in practice. Based on lessons from the past death penalty reforms, this research will examine progress and problems in China's latest reforms in order to better reform the current death penalty system towards its eventual abolition from the perspective of human rights protection.

\section{China's death penalty reforms in 2015}

Following the 2011 Amendment, with 13 crimes punishable by death cancelled, ${ }^{2}$ the 2015 Amendment further cancelled nine more crimes punishable by death in China, such as fraud, organizing prostitution, forced prostitution and so on. ${ }^{3}$ The latest legislation on China's death penalty reform could help limit the legal scope of applying the death penalty. After the deletion in new revisions, there are 46 crimes in the current Criminal Law of the PRC that can be applied to the death penalty. Compared with 71 crimes from 1982 to1985, over one third crimes punishable by death have been cut down. Clearly, the most significant progress on reforming the death penalty system in recent years has been the continuous decline in the number of crimes punishable by death and potential executions. The 2015 Amendment also provides that in corruption or bribery cases, if the death penalty that convicts face is suspended, the people's court may decide to reduce the suspension of execution to life imprisonment, without commutation or parole based on the circumstances of the involved crimes, upon the end of the two-year suspension period of execution of the death sentence. Such revisions are expected to preventing such criminals' sentences from being commuted to other lenient punishments in practice, conducive to embodying the criminal law principle of adapting crimes and punishments. So, in such capital cases, convicts only face life-long imprisonment upon the end of a

${ }^{1}$ Susan Munro, Lin Yang. China Promulgates the Ninth Amendment to the PRC Criminal Law. Steptoe. 2015.

${ }^{2}$ Criminal Law of the People's Republic of China (2017 Amendment PKULAW Version). 2017.

${ }^{3}$ Full text: Progress in the Legal Protection of Human Rights in China. 2017. suspension of execution. It is designed to prevent reducing convicts' capital punishment to light one by means of commutation or parole. ${ }^{4}$

\section{Case Study}

Even with new revisions, not all of economic or non-violent crimes punishable by death have been cut in criminal law. Also, the scope of the death penalty applies to capital cases with doubts in evidence or procedure, which may increase the high risk of wrongful convictions in practice. It is necessary to explore the actual effect of the death penalty system in practice, which could be further demonstrated by a recent case study as follows:

The case occurred on June 22, 2017, in Hangzhou, Zhejiang province. It had caused four persons' death, including one mother and three children. On July 1, 2017, the Hangzhou Public Security Bureau arrested Mo Huanjing, due to suspicion of arson and theft. On August 21, 2017, the Hangzhou City Procuratorate filed a public prosecution against the defendant Mo Huanjing. On December 21, 2017, the Hangzhou Intermediate People's Court held a court hearing on the case. But the defendant's lawyer objected to the court's jurisdiction so that the court had to announce the suspension of the hearing. Later, her lawyer was arrested by local police. On February 1, 2018, Mo Huanjing continued to hold trials in the case of arson and theft. On February 9, the case was publicly pronounced in the first instance, and the defendant Mo Huanjing was sentenced to death for the crimes of arson and theft. On June 4, 2018, the appeal was dismissed and the first-instance death sentence was upheld in the second instance. Finally on September 21, 2018, Mo Huanjing was executed. There are two major points worthy of note. The first is on the scope of the death penalty. In this case, the accused were sentenced to death for the crime of arson, a violent crime leading to death, rather than theft under very serious circumstances. The shrinking scope of the death penalty in new revisions can help reduce the number of death sentences and executions in practice, which is a part of recent human rights progress in China. The second is on the right to defence. After the defence lawyer argued against the court jurisdiction, the presiding judge informed the lawyer of its legal jurisdiction over the case by law. Although the lawyer left the court without authorization to refuse continuing to defend justice for his client, the defendant accepted two lawyers' legal aid who were appointed by the Hangzhou Legal Aid Center, in order to ensure her defence right.

${ }^{4}$ See Amendment IX to Criminal Law of the PRC provides the prohibition of commutation or parole imposed on serious or major convicts in corruption or bribery cases. 


\section{Significant shortcomings in law and practice}

In criminal law of China, the scope of the death penalty includes economic and non-violent crimes. This is much broader than the requirement of international standards, namely, the most serious crimes or violent crimes leading to death. Although China has signed the International Covenant on Civil and Political Rights, there is still a long way to go before its abolition of the death penalty in law, not to mention that in practice. In procedure, the final review of the death penalty approved by the Supreme People's Court (SPC) also has some shortcomings. For example, some judges do not allow defence lawyers to read case documents even if they are permissible by law and involve key evidence. This limitation often leads to the consequence that in capital cases defence lawyers cannot fully understand case details or guarantee the legitimate rights or interests of the defendants facing the death penalty. Among legal documents on final review of the death penalty, there is no way to find lawyers' opinions that SPC judges wrote down, not to mention fully considering their views. In addition, the SPC has no time limit for its final review of the death penalty so that in practice the period is particularly at random, sometimes ranging from several months to years. Due to the large demand for the personnel of the SPC in the review work, some local judges have to participate into the review and help examine capital cases again, though they are competent to do so. Many procedures for death penalty review are not transparent, but closed and administrative. The current review process has a strong color of administration. Specifically, the review continues the traditional mode of handling capital cases. The involved steps often include the official record of review, written examination of collegiate collegial panel, and decisions made by the trial court's committee. Despite with investigation, the mode is still an internal evaluation mechanism.

\section{Future reform on the death penalty}

In order to reform the death penalty review procedure from an internal evaluation to cross-examination, it is desirable for China to clearly define it as the trial procedure. Thus, the litigation reform should be carried out in order to establish a further trial system for the final review of death sentences. At the same time, those facing the death penalty should be fully ensured to get access to defence. Given that defence lawyers can defence justice for the accused, providing the most possible defense channels for criminal suspects and lawyers would be the best safety net to guarantee procedural fairness and reduce wrongful convictions in capital cases. This requires banning any forms of professional risks that defence lawyers often face both in law and practice. In a long march towards the eventual abolition of the death penalty, China should take gradual measures to totally abolish it as early as possible step by step. At the very least, China should suspend all of executions in any capital cases as soon as possible in order to prevent and reduce the risk of wrongful executions in practice and better protect human rights of those facing the death penalty. Following the practical action, China should proceed with greatly reduce the large number of capital crimes and abolishing all of economic crimes and non-violent crimes punishable by death in future legislative reforms on the death penalty system of China. Finally, China should totally abolish the death penalty in peace time so as to turn all of death sentences, applicable to most serious crimes with a shrinking scope, into life imprisonment with commutation or parole.

\section{Conclusion}

Given significant shortcomings in law and in practice, the latest death penalty reforms in China have been more symbolic than substantive so that they cannot mend major flaws in China's death penalty system. Further reforms on the death penalty are needed in creative ways in order to better fill in the loopholes in legislation and ensure the actual implementation of these reforms. Apart from suspending executions, abolishing the death penalty used for ordinary crimes without leading to death and defence lawyers' professional risks, increased cross-examination and transparency in the final review of death sentences could help improve human rights progress and reduce errors in China's death sentences.

\section{Acknowledgments}

None

\section{Conflicts of interest}

The author declares that there are no conflicts of interest. 